\title{
PENGARUH PENAMBAHAN BERBAGAI EKSTRAK BAHAN PEWARNA ALAMI TERHADAP DAYA TERIMA SOSIS IKAN LELE (CLARIAS BATRACHUS)
}

\author{
Muntikah $^{1}$, Putri Wahyuningsih ${ }^{2}$ \\ ${ }^{1}$ Dosen Jurusan Gizi Poltekkes Kemenkes Jakarta II \\ ${ }^{2}$ Alumni Jurusan Gizi Poltekkes Kemenkes Jakarta II \\ Email: munti_des@yahoo.com
}

\begin{abstract}
Effect of The Addition of Some Extract Natural Dyes Against Durability of Catfish Sausage (Clarias batrachus). The sausage is a favorite food of the family, from children to adults. Need takes innovation to create products sausage with diversification of food used that replaced by fish that contains high nutritional value as a source of protein, easy to digest and low in cholesterol. So one of the effort to make sausage catfish interesting by adding natural dyes from vegetable extracts include carrots, spinach, and bits to produce colorful and healthy sausage. This study was conducted in June 2016. This study design is experimen with completely randomized design (CRD) 4 treatments and 3 replications. The results showed there were effect of the addition of some natural dyes to color, flavor, texture, and the level of preference sausage catfish $(\alpha=0,05)$. The results of the organoleptic tests, catfish sausage are selected by the addition of beet extract $12.6 \%$. For preference level early children color sausage also have the same rating as much as $80 \%$. As for the taste of the sausage with the addition of beet and carrot extract, $100 \%$ of children spend it. Values on the analysis of nutrients per 100 grams of sausage catfish elected: energy 158 kcal, $12.1 \%$ protein, $8.63 \%$ fat, $8.02 \%$ carbohydrates.
\end{abstract}

Keywords: Sausage, Catfish, Dyes

\begin{abstract}
Abstrak: Pengaruh Penambahan Berbagai Ekstrak Bahan Pewarna Alami terhadap Daya Terima Sosis Ikan Lele (Clarias batrachus). Sosis adalah makanan favorit keluarga, dari anakanak hingga orang dewasa. Perlu dilakukan inovasi untuk menciptakan produk sosis dengan diversifikasi pangan menggunakan bahan pengganti ikan yang mengandung nilai gizi yang tinggi sebagai sumber protein, mudah dicerna dan rendah kolesterol. Jadi salah satu upaya untuk membuat sosis ikan lele yang menarik dengan menambahkan pewarna alami dari ekstrak sayur wortel, bayam, dan bit untuk menghasilkan sosis berwarna-warni dan sehat. Penelitian ini dilakukan pada bulan Juni 2016. Desain penelitian ini Eksperimen dengan completely randomized design (CRD) 4 perlakuan dan 3 ulangan. Hasil penelitian menunjukkan ada pengaruh penambahan beberapa pewarna alami untuk warna, rasa, tekstur, dan tingkat kesukaan sosis ikan lele $(\alpha=0,05)$. Hasil uji organoleptik, sosis ikan lele yang dipilih oleh penambahan ekstrak bit $12,6 \%$. Untuk tingkat preferensi sosis warna anak sejak dini juga memiliki sama Peringkat sebanyak $80 \%$. Adapun rasa sosis dengan penambahan bit dan ekstrak wortel, $100 \%$ dari anakanak menghabiskan itu. Nilai-nilai pada analisis nutrisi per 100 gram ikan lele sosis terpilih: energi $158 \mathrm{kkal}, 12,1 \%$ protein, $8,63 \%$ lemak, $8.02 \%$ karbohidrat.
\end{abstract}

Kata kunci: Sosis, Ikan lele, Pewarna

Sosis merupakan makanan kegemaran keluarga, dari anak-anak sampai dengan orang dewasa. Biasanya sosis sangat praktis diolah sebagai sarapan pagi, bekal sekolah, maupun snack (Alamsyah, 2005). Hasil observasi di masyarakat, banyak sosis yang dijual oleh pedagang kaki lima yang diolah dengan cara digoreng maupun dibakar sesuai dengan pilihan konsumen.

Sosis secara umum dibuat dari daging sapi dan ayam, sosis daging sapi mengandung lemak sebanyak $42,3 \%$. Tingginya kadar lemak dalam sosis dapat meningkatkan kadar kolesterol Low Density Lipoprotein (LDL) dalam darah. Salah satu efek negatif tingginya kolesterol darah dapat menimbulkan sumbatan aliran darah sehingga beresiko terserang penyakit jantung dan stroke (Physician Committee).

Dalam rangka penganekaragaman pangan sosis daging sapi dapat digantikan dengan daging ikan yang rendah kolesterol. Ikan mengandung asam lemak tidak jenuh tinggi, asam lemak omega-3, mudah dicerna dan rendah kolesterol. Fungsi asam lemak omega 3 untuk membantu 
perkembangan sel otak pada anak dan memelihara sel otak pada orang lanjut usia. Konsumsi ikan menurut Kementerian Kelautan dan Perikanan RI tahun 2014 konsumsi ikan di Indonesia masih rendah hanya $38 \mathrm{~kg}$ per kapita per tahun, sedangkan negara lain sudah mencapai $70-140 \mathrm{~kg}$ per kapita per tahun.

Produksi ikan lele pada tahun 2011 mencapai 340.674 ton. Pengolahan ikan lele belum maksimal, di masyarakat pengolahan ikan lele hanya digoreng saja, sehingga kurang disukai anak-anak. Sosis salah satu alternatif makanan trend saat ini dan disukai anak-anak. Bahan dasar yang digunakan pada penelitian ini adalah ikan lele lokal karena memiliki rasa lebih enak, mengandung karoten $12.070 \mu \mathrm{g}$, vitamin A 210 IU (Puslitbang 1991), asam amino lisin dan leusin yang baik untuk pertumbuhan dan perkembangan anak (Erwin, 2011).

Warna daging ikan lele kurang menarik bagi anak-anak untuk dikonsumsi. Sebaliknya anak-anak lebih suka dengan makanan yang berwarna-warni (Winneke, 2012). Salah satu upaya agar penampilan sosis menarik bagi anakanak yaitu dengan menambahkan bahan pewarna alami yang berbeda seperti bayam, wortel dan bit. Jenis sayuran tersebut dapat memberikan pigmen yang berwarna warni untuk membuat produk agar lebih menarik. Menurut Muchtadi 2010 pewarna alami yang digunakan mengadung pigmen klorofil, karoten dan betalain yang berfungsi sebagai anti oksidan.

Ekstrak pewarna alami aman untuk kesehatan, dan dapat meningkatkan kandungan vitamin dan mineral produk sosis ikan lele. Berdasarkan latar belakang di atas peneliti tertarik untuk membuat produk sosis ikan lele yang ditambahkan berbagai ekstrak pewarna alami yang dapat memberikan warna warni sosis ikan lele yang menarik dan disukai oleh konsumen.

\section{METODE PENELITIAN}

Penelitian ini termasuk penelitian eksperimen yaitu 4 unit percobaan dengan 3 kali replikasi dan menggunakan Rancangan Acak Lengkap (RAL).

Ruang lingkup penelitian ini meliputi pembuatan produk, mengidentifikasi berbagai ekstrak pewarna alami dan menganalisis zat gizi proksimat sosis yang disukai, daya terima sosis ikan lele dan melakukan aplikasi pada anak PAUD dan anak TK.

Pelaksanaan penelitian Bulan Juni 2016, di Laboratorium Ilmu Teknologi Pangan dan
Laboratorium Uji Cita Rasa Jurusan Gizi Poltekkes Kemenkes Jakarta II, Laboratorium Balai Besar Industri Agro untuk analisis zat gizi proksimat, PAUD Melati dan TK Ar-Ridwan untuk aplikasi produk sosis ikan lele.

Data dikumpulkan dengan menggunakan formulir uji organoleptik oleh panelis agak terlatih sebanyak 31 panelis. Data hasil penilaian panelis disusun dan dianalisis secara deskriptif berdasarkan persentase. Untuk mengetahui ada atau tidaknya pengaruh dianalisis menggunakan statistik non parametrik, jika terdapat pengaruh maka dilakukan uji lanjut Wayne W Daniel.

\section{Alat dan Bahan}

Alat Pengumpulan data adalah Formulir uji organoleptik dan panelis agak terlatih sedangkan bahan adalah produk sosis ikan lele dengan penambahan ekstrak pewarna alami.

\section{Prosedur Pembuatan Sosis Ikan Lele}

1. Bersihkan ikan lele kemudian cuci bersih, ambil dagingnya kemudian timbang $500 \mathrm{~g}$

2. Kupas dan bersihkan wortel, bit dan bayam lalu cuci bersih

3. Kemudian wortel dan bit parut secara terpisah kemudian saring ambil ektraknya.

4. Bayam dicuci bersih kemudian haluskan dengan food processor dan saring ekstraknya.

5. Timbang tepung tapioka $10 \%$, es batu $10 \%$, telur ayam $100 \mathrm{~g}$, bawang merah $6 \%$, bawang putih $3 \%$, lada bubuk $1 \%$, gula pasir $1 \%$, dan garam $1,5 \%$.

6. Haluskan daging ikan lele menggunakan food processor dan tambahkan es batu, tepung tapioka, telur, dan bumbu.

7. Tambahkan ekstrak pewarna alami masingmasing wortel, bayam hijau, dan bit

8. Cetak dengan memasukkan masing-masing adonan kedalam casing.

9. Isi hingga padat dan ikat ujung atas dan bawah menggunakan tali benang.

10. Oven sosis 15 menit dengan suhu $60^{\circ} \mathrm{C}$.

11. Kukus selama 30 menit.

\section{HASIL}

\section{Penelitian Pendahuluan}

Penelitian pendahuluan dilaksanakan pada tanggal 2-13 Mei 2016 untuk menentukan formula sosis ikan lele dengan penambahan pewarna alami dari ekstrak sayuran. Penelitian 
pendahuluan dilakukan tiga tahap, yaitu pada tahap pertama bertujuan untuk menentukan konsentrasi tepung tapioka dan bumbu-bumbu yang digunakan dalam pembuatan sosis ikan lele. Konsentrasi tepung tapioka yang digunakan yaitu sebesar $10 \%$. Hasil tekstur sosis kenyal, rasa sosis terlalu asin dan aroma bawang putih yang menyengat. Tahap 2 penggunaan bumbu dikurangi sedangkan untuk menambah cita rasa ditambah bawang merah. Konsentrasi ekstrak pewarna alami berdasarkan per $100 \mathrm{~g}$ bahan, didapat ekstrak wortel $44 \%$, bayam hijau $29 \%$, dan bayam merah $27 \%$. Sosis yang menggunakan bayam merah warnanya menjadi coklat dan tidak menarik. Tahap ke 3 penggunaan ekstrak bayam merah diganti dengan bit yang mempunyai warna ungu yang mencolok diharapkan dapat memberikan warna yang menarik.

\section{Penelitian Utama}

Penelitian utama merupakan lanjutan dari penelitian pendahuluan meliputi pembuatan produk, uji organoleptik, analisis zat gizi, dan aplikasi produk pada anak. Untuk lebih jelasnya mengenai formulasi produk sosis ikan lele dapat dilihat pada tabel 1 .

Tabel 1. Formulasi Sosis Ikan Lele

\begin{tabular}{lrrrr}
\hline \multirow{2}{*}{ Bahan Makanan } & \multicolumn{4}{c}{ Konsentrasi } \\
& \multicolumn{4}{c}{ Alami } \\
\cline { 2 - 5 } & T1 & T2 & T3 & T4 \\
\hline Ikan lele (g) & 500 & 500 & 500 & 500 \\
Tepung tapioka & 50 & 50 & 50 & 50 \\
(g) & & & & \\
Bawang merah & 30 & 30 & 30 & 30 \\
(g) & & 15 & 15 & 15 \\
Bawang putih (g) & 15 & 5 & 5 & 5 \\
Lada putih (g) & 5 & 5,5 & 7,5 & 7,5 \\
Garam (g) & 7,5 & 7,5 \\
Gula pasir (g) & 5 & 5 & 5 & 5 \\
\hline Ketrangan & & & &
\end{tabular}

Keterangan :

T1 : Penambahan ekstrak 0\%

T2 : Penambahan ekstrak wortel $17,4 \%$

T3 : Penambahan ekstrak bayam $13 \%$

T4 : Penambahan ekstrak bit $12,6 \%$

\section{Gambaran Umum Produk Sosis Ikan Lele}

Produk sosis dengan bahan dasar ikan lele yang ditambahkan ekstrak wortel, bayam, dan bit memberikan warna sesuai dengan pigmen yang terkandung dalam ekstrak yang memberikan warna alami. Penilaian sosis ikan lele secara organoleptik meliputi: warna, aroma, rasa, tekstur, dan tingkat kesukaan.

Hasil penilaian organoleptik sosis ikan oleh panelis meliputi : T1 bewarna putih krem, aroma agak amis, rasa gurih dan tektur kenyal; T2 berwarna kuning, aroma agak amais, rasa agak gurih , tektur tidak kenyal; T3 berwarna hijau muda, aroma tidak amis, rasa agak gurih dan tektur agak kenyal; T4 berwarna krem keunguan, aroma tidak amis, rasa gurih dan tektur kenyal.

Untuk lebih jelas mengenai warna sosis ikan lele yang dihasilkan, dapat dilihat pada gambar 1.

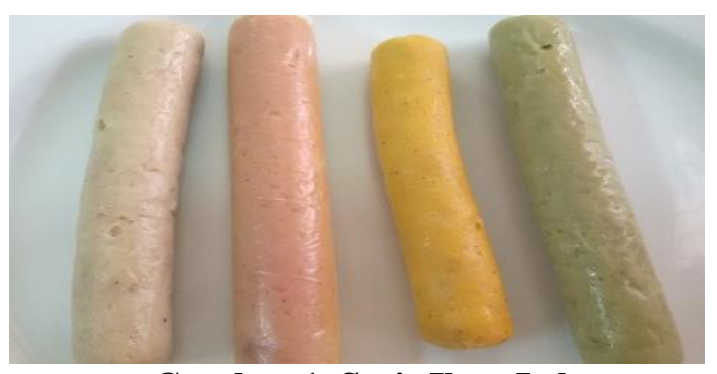

Gambar 1. Sosis Ikan Lele

Penilaian uji organoleptik dilakukan pada bulan Juni 2016 di Laboratorium Uji Cita Rasa Jurusan Gizi Poltekkes Kemenkes Jakarta II. Jumlah panelis 31 orang, kriteria yang dinilai meliputi warna, aroma, rasa, tekstur, dan tingkat kesukaan.

\section{Analisis Proksimat}

Kandungan gizi pada sosis ikan lele dengan penambahan ekstrak bit yang mendapat penilaian tertinggi selanjutnya dilakukan analisis proksimat.

Tabel 2. Hasil Analisis Gizi Sosis Ikan Lele Terpilih

\begin{tabular}{lccc}
\hline \multirow{2}{*}{ Parameter } & \multirow{2}{*}{ Satuan } & \multicolumn{2}{c}{ Hasil } \\
\cline { 3 - 4 } & & Simplo & Duplo \\
\hline Air & $\%$ & 69,4 & 69,4 \\
\hline Abu & $\%$ & 1,85 & 1,82 \\
\hline Protein $(\mathrm{N} \mathrm{x} \mathrm{6,25)}$ & $\%$ & 12,1 & 12,0 \\
\hline Lemak & $\%$ & 8,63 & 8,54 \\
\hline Karbohidrat & $\%$ & 8,02 & 8,24 \\
\hline Energi & Kkal/ & 158 & 158 \\
& $100 \mathrm{~g}$ & & \\
\hline
\end{tabular}

Kadar air sosis yang dihasilkan adalah $69,4 \%$ (bb). Syarat mutu sosis berdasarkan SNI 01-3820-1995 menyatakan kadar air max sosis daging $67 \%(\mathrm{bb})$. 


\section{Aplikasi Produk Sosis}

Daya terima dinilai berdasarkan sosis yang mampu dihabiskan oleh anak. Dapat dikategorikan suka jika anak menghabiskan sosis ikan lele yang disajikan. Pengujian dilakukan dengan memperlihatkan 4 sosis dengan warna yang berbeda yaitu putih krem, ungu, kuning, dan hijau, kemudian anak tersebut memilih warna yang paling disukai dan mengurutkan warna dari yang paling disukai hingga yang kurang disukai.

Setelah memilih, kemudian anak diminta untuk mencicipi sosis yang dipilih. Berikut ini merupakan hasil tingkat kesukaan warna terhadap sosis ikan lele menurut anak PAUD dan TK.

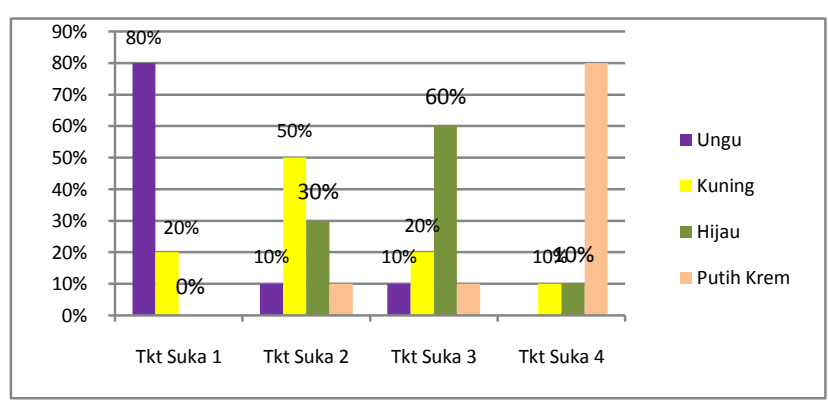

Gambar 2. Grafik Tingkat kesukaan warna

Berdasarkan grafik tingkat kesukaan warna terhadap sosis ikan lele yang disajikan, warna yang pertama kali dipilih dan disukai paling banyak yaitu warna ungu sebesar $80 \%$.

\section{PEMBAHASAN}

\section{Warna}

Penilaian warna sosis ikan lele tanpa penambahan ektrak $\mathrm{T} 1$ sebesar $59,1 \%$ panelis menyatakan warna putih krem, Penambahan ekstrak wortel T2 sebanyak 65,6\% menyatakan warna sosis yaitu kuning. Sosis ikan lele dengan penambahan ekstrak bayam T3 sebanyak 76,3\% panelis menyatakan warna sosis hijau muda. Dan sosis ikan lele dengan penambahan ekstrak bit T4 sebanyak $72 \%$ menyatakan warna sosis krem keunguan.

Warna kuning pada sosis ikan lele yang ditambahkan ekstrak wortel disebabkan oleh pigmen yang terkandung dalam wortel yaitu karotenoid. Dalam pengolahan sayuran dan buahbuahan, kerusakan karotenoid selama pemasakan sangat sedikit (Muchtadi, 2010), sehingga warna kuning yang terbentuk tidak berubah saat proses pemasakan.
Warna sosis ikan lele yang dihasilkan pada sosis dengan penambahan ekstrak bayam hijau yaitu hijau muda. Hal ini dapat disebabkan karena reaksi oksidasi. Klorofil menghasilkan produk yang tidak berwarna akibat dari teralomerasinya klorofil dan pecahnya cincin tetrapirol. Reaksi oksidasi ini dapat terjadi secara enzimatis maupun non enzimatis. Oksidasi secara enzimatis melibatkan enzim lipoksigenase yang terdapat di sebagian besar sayuran dan buahbuahan (SEAFAST IPB, 2012).

Sosis yang ditambahkan ekstrak bit, warna sosis ikan lele yang dihasilkan sebelum dipanaskan yaitu ungu, hal ini disebabkan oleh pigmen yang terkandung dalam bit merah yaitu betalain. Pigmen betalain yang terdapat pada bit terdiri dari dua kelompok yaitu pigmen merah violet betasianin dan pigmen kuning betaxantin. Betasianin pada bit memiliki stabilitas yang rendah jika terpapar oleh panas, logam, dan cahaya, sehingga pigmen terdegradasi dan warna memudar (SEAFAST IPB, 2013), karena itu, sosis ikan lele dengan penambahan ekstrak bit setelah pemanasan, warna sosis berubah menjadi krem keunguan hingga ungu kekuningan.

Hasil analisis uji statistik non parametrik Friedman, diperoleh hasil $\mathrm{x}^{2}$ hitung 135,1 > $\mathrm{x}^{2}$ tabel 19,675 yang artinya ada pengaruh pada penambahan beberapa bahan pewarna alami terhadap warna sosis ikan lele. Untuk mengetahui ada tidaknya perbedaan dalam dua perlakuan, dilakukan uji beda antar perlakuan menggunakan Wayne W Daniel dengan $\alpha=0,05$ terdapat perbedaan warna yang nyata pada perlakuan $\mathrm{T} 1$ dengan $\mathrm{T} 3$, $\mathrm{T} 1$ dengan $\mathrm{T} 4, \mathrm{~T} 2$ dengan $\mathrm{T} 3, \mathrm{~T} 2$ dengan $\mathrm{T} 4$, dan $\mathrm{T} 3$ dengan $\mathrm{T} 4$.

\section{Aroma}

Menurut Ketaren (1986) aroma amis pada ikan disebabkan oleh terbentuknya trimetil-amin, dalam otot ikan atau dalam jaringan hewan terdapat dalam bentuk persenyawaan oksida yaitu trimetil-amin oksida $\left(\mathrm{NMe}_{3}\right)$ akibat oksidasi trimetil-amin oleh peroksida.

Hasil penilaian panelis tertinggi sebanyak $50,5 \%$ pada sosis tanpa ekstrak dan sebanyak $45,2 \%$ pada sosis dengan penambahan ekstrak wortel menyatakan penilaian yang sama terhadap aroma sosis ikan lele yaitu agak amis. Sedangkan pada sosis dengan penambahan ekstrak bayam sebanyak 48,4\% dan sebanyak $51,6 \%$ pada sosis dengan penambahan ekstrak bit menyatakan penilaian yang sama pada aroma sosis ikan lele yaitu tidak amis. Hal ini kemungkinan disebabkan oleh aroma ekstrak bit dan bayam dapat menetralisir aroma amis. 
Hasil analisis uji statistik non parametrik Friedman yang dilakukan diperoleh hasil $\mathrm{x}^{2}$ hitung 13,9 $<\mathrm{x}^{2}$ tabel 19,675 yang artinya tidak ada pengaruh pada penambahan beberapa bahan pewarna alami terhadap aroma sosis ikan lele.

\section{Rasa}

Hasil penilaian rasa tertinggi yaitu $\mathrm{T} 1$ sebanyak $66,7 \%$ panelis menyatakan rasa sosis gurih, sosis dengan penambahan ekstrak bit T4 sebanyak $58,1 \%$ panelis menyatakan rasa sosis gurih. Sedangkan sosis dengan penambahan ekstrak wortel $\mathrm{T} 2$ mendapat penilaian tertinggi sebanyak 48,4\% menyatakan rasa sosis agak gurih dan pada sosis dengan penambahan ekstrak bayam menyatakan penilaian yang sama yaitu dengan kriteria rasa agak gurih T3 sebanyak panelis $41,9 \%$. Rasa sosis agak gurih dapat dipengaruhi oleh banyaknya pemberian bahan pewarna alami terhadap sosis ikan lele sehingga penilaian panelis pada kriteria gurih semakin berkurang.

Hasil analisis uji statistik non parametrik Friedman ada pengaruh penambahan beberapa bahan pewarna alami terhadap rasa sosis ikan lele. Selanjutnya dilakukan uji beda Wayne W Daniel dengan $\alpha=0,05$ diperoleh terdapat perbedaan rasa yang nyata yaitu pada perlakuan $\mathrm{T} 1$ dengan $\mathrm{T} 2$, $\mathrm{T} 1$ dengan $\mathrm{T} 3$, dan $\mathrm{T} 2$ dengan $\mathrm{T} 4$, dan $\mathrm{T} 3$ dengan $\mathrm{T} 4$.

\section{Tekstur}

Hasil penilaian panelis tertinggi tekstur sosis ikan lele tanpa penambahan ekstrak T1 sebanyak $48,4 \%$ dan T4 sebanyak $45,2 \%$ panelis menyatakan tektur yang sama dengan kriteria kenyal. Sedangkan sosis dengan penambahan ekstrak bayam T3 sebanyak 41,9\% panelis memberikan penilaian tektur kenyal. Sosis dengan penambahan esktrak wortel sebanyak $48,4 \%$ panelis menyatakan kriteria tektur tidak kenyal. Hal ini dipengaruhi oleh banyaknya penambahan cairan atau ekstrak bahan pewarna alami pada sosis ikan lele, sehingga mempengaruhi tekstur sosis tidak kenyal.

Hasil analisis uji statistik non parametric ada pengaruh penambahan beberapa bahan pewarna alami terhadap tekstur sosis ikan lele. Untuk kemudian dilakukan uji lanjut Wayne W Daniel diperoleh terdapat perbedaan tekstur yang nyata yaitu pada perlakuan $\mathrm{T} 1$ dengan $\mathrm{T} 2, \mathrm{~T} 1$ dengan $\mathrm{T} 3$, dan $\mathrm{T} 2$ dengan $\mathrm{T} 3, \mathrm{~T} 2$ dengan $\mathrm{T} 4$, dan T3 dengan T4.

\section{Tingkat Kesukaan secara Umum}

Hasil penilaian panelis menyatakan suka pada sosis tanpa penambahan ekstrak yaitu sebanyak $46,2 \%$, penambahan ekstrak wortel sebanyak $25,8 \%$, dengan ekstrak bayam sebanyak 20,4\%, dengan penambahan ekstrak bit sebanyak $58,1 \%$. Hal ini disebabkan karena dari keseluruhan aspek organoleptik sosis ikan lele yang dapat diterima oleh panelis, seperti warna sosis ikan lele, aroma sosis ikan lele yang tidak amis, rasa sosis ikan lele yang gurih dan tekstur sosis ikan lele yang kenyal.

Hasil analisis uji statistik non parametrik Friedman ada pengaruh penambahan beberapa bahan pewarna alami terhadap tingkat kesukaan sosis ikan lele. Sedangkan hasil uji beda Wayne W Daniel dengan $\alpha=0,05$ diperoleh terdapat perbedaan tingkat kesukaan yang nyata yaitu pada perlakuan $\mathrm{T} 1$ dengan $\mathrm{T} 2$, $\mathrm{T} 1$ dengan $\mathrm{T} 3, \mathrm{~T} 1$ dengan T4, T2 dengan T4, dan T3 dengan T4.

\section{Analisis Proksimat}

Setelah dilakukan analisis proksimat, kadar air sosis yang dihasilkan adalah $69,4 \%$ (bb). Syarat mutu sosis berdasarkan SNI 013820-1995 menyatakan kadar air max sosis daging $67 \%$ (bb). Kadar air sosis yang dihasilkan berada di atas persyaratan SNI. Hal ini disebabkan oleh penambahan cairan ekstrak bit pada sosis ikan lele sehingga meningkatkan kandungan air dalam sosis yang dihasilkan.

Menurut Soebito (1988), kadar abu merupakan unsur mineral sebagai sisa yang tertinggal setelah bahan dibakar sampai bebas unsur karbon. Kadar abu juga dapat diartikan sebagai komponen yang tidak mudah menguap, tetap tinggal dalam pembakaran dan pemijaran senyawa organik. Syarat mutu sosis daging berdasarkan SNI 01-3820-1995, kadar abu maksimum pada sosis daging adalah max 3,0\% (bb). Kadar abu sosis ikan lele yang dihasilkan pada penelitian ini adalah 1,82 sampai $1,85 \%$ (bb). Kadar abu sosis ikan lele yang dihasilkan masih berada di bawah persyaratan SNI, sehingga dapat dikatakan bahwa kadar abu sosis ikan lele dengan penambahan ekstrak bit sebagai pewarna sudah memenuhi persyaratan mutu sosis berdasarkan SNI.

Menurut Winarno (1997), protein adalah sumber asam amino yang mengandung unsur $\mathrm{C}$, $\mathrm{H}, \mathrm{O}$, dan $\mathrm{N}$ yang tidak dimiliki oleh lemak dan karbohidrat. Pengukuran kadar protein sosis mengunakan metode Kjeldhal yang didasarkan pada pengukuran kadar nitrogen total. Kandungan protein dapat dihitung dengan 
mengasumsikan rasio tertentu antara protein terhadap nitrogen untuk contoh sosis. Karena unsur nitrogen bukan hanya berasal dari protein, maka metode ini mendasarkan pada asumsi kandungan nitrogen adalah protein adalah $16 \%$. Untuk mengubah dari kadar nitrogen ke dalam kadar protein maka digunakan angka faktor konversi sebesar 100/16 atau 6.25.

Protein yang terdapat dalam sosis ikan lele sebagian besar berasal dari ikan lele. Menurut syarat mutu sosis daging berdasarkan SNI 013820-1995, kadar protein min dalam sosis adalah $13,0 \%$ (bb). Kadar protein sosis ikan lele yang dihasilkan pada penelitian adalah $12,0 \%$ sampai $12,1 \%$ (bb). Jika dibandingkan dengan persyaratan kadar protein min sosis dengan bahan dasar daging (SNI), kadar protein sosis ikan lele pada penelitian ini berada dibawah kadar minimum protein pada SNI sosis daging. Hal ini disebabkan bahan dasar yang digunakan yaitu ikan lele. Ikan lele memiliki kandungan protein lebih rendah dibandingkan dengan daging sapi. Dalam $100 \mathrm{~g}$ ikan lele mengandung protein sebesar $14,8 \mathrm{~g}$ sedangkan daging sapi $18,8 \mathrm{~g}$. Oleh sebab itu, penggantian penggunaan daging sapi dengan ikan lele dapat mengurangi kandungan protein dalam sosis yang dihasilkan.

Lemak dalam pembuatan sosis berguna untuk membentuk sosis yang kompak dan empuk serta memperbaiki aroma dan rasa sosis. Penambahan lemak yang terlalu banyak akan mengakibatkan hasil sosis yang keriput, sedangkan penambahan yang terlalu sedikit akan menghasilkan sosis yang keras dan kering (Anonim, 2002).

Kandungan lemak sosis ikan lele yang dihasilkan adalah 8,54\% sampai 8,63\% (bk), sedangkan menurut SNI 01-3820-1995, kadar lemak maksimal dalam sosis adalah $25,0 \%$. Jika dibandingkan dengan persyaratan kadar lemak max pada SNI, kadar lemak produk berada di bawah persyaratan kadar lemak max pada SNI, sehingga dapat dikatakan bahwa berdasarkan kadar lemaknya, sosis ikan lele yang dihasilkan telah memenuhi persyaratan mutu sosis jika mengacu pada persyaratan mutu sosis pada SNI.

Tepung tapioka dalam pembuatan sosis berfungsi untuk menarik air, memeberi warna khas, membentuk tekstur yang padat, memperbaiki stabilitas emulsi, menurunkan penyusutan waktu pemasakan, dan memperbaiki citarasa.

Karbohidrat memiliki peranan penting dalam menentukan karakteristik bahan makanan, misalnya rasa, warna, tekstur dan lain-lain (Winarno 1984). Bahan yang menjadi sumber karbohidrat pada pembuatan sosis yaitu tepung tapioka dan gula. Hasil analisis menunjukkan kadar karbohidrat sosis yang dihasilkan adalah $8,02 \%$ sampai $8,24 \%$ (bb). Jika dibandingkan dengan persyaratan maksimal kadar karbohidrat sosis daging yang tercantum pada SNI yaitu $8,0 \%$, kadar karbohidrat sosis yang dihasilkan hampir sama dan sedikit lebih tinggi.

\section{Aplikasi Produk Sosis}

Sosis ikan lele yang berwarna-warni hasil penambahan ekstrak alami, dilakukan uji daya terima terhadap warna sosis pada anak PAUD "Melati" dan TK "Ar-Ridwan". Daya terima dinilai berdasarkan sosis yang mampu dihabiskan oleh anak. Dapat dikategorikan suka jika anak menghabiskan sosis ikan lele yang disajikan. Pengujian dilakukan dengan memperlihatkan 4 sosis dengan warna yang berbeda yaitu putih krem, ungu, kuning, dan hijau, kemudian anak tersebut memilih warna yang paling disukai dan mengurutkan warna dari yang paling disukai hingga warna yang kurang disukai.

Berdasarkan gambar-2, grafik tingkat kesukaan warna terhadap sosis ikan lele yang disajikan, warna yang pertama kali dipilih dan disukai paling banyak yaitu warna ungu sebesar $80 \%$. Lalu tingkat kesukaan warna kedua yaitu pada warna kuning sebesar $50 \%$. Tingkat kesukaan warna ketiga yaitu warna hijau sebesar $60 \%$, dan tingkat kesukaan warna terakhir yaitu warna putih krem sebesar $80 \%$. Hal ini disebabkan karena anak-anak lebih suka dengan makanan yang berwarna (Winneke, 2012).

Daya terima sosis ikan lele yang disajikan dinilai dari sosis yang mampu dihabiskan oleh anak PAUD dan TK sosis yang berwarna krem ungu dan kuning, sedangkan sosis yang berwarna hijau maupun kren tanpa penambahan ekstrak masing-masing $80 \%$ dan $70 \%$

\section{Analisis Biaya Bahan Baku Sosis Ikan Lele}

Biaya yang diperlukan untuk membuat 100g sosis ikan lele T1 sebesar Rp. 9.574,- T2 sebesar Rp. 9.831,- T3 sebesar Rp. 11.180,dan T4 sebesar Rp. 12.299,-

\section{SIMPULAN}

1. Formulasi sosis ikan lele yang digunakan dengan penambahan bahan pewarna alami terdiri dari 4 formulasi, yaitu penambahan ekstrak $0 \%$, ekstrak wortel $17,4 \%$, esktrak bayam $13 \%$, dan esktrak bit $12,6 \%$. 
2. Ada pengaruh penambahan berbagai ekstrak bahan pewarna alami terhadap warna, rasa, tekstur, dan tingkat kesukaan sosis ikan lele.

3. Tidak ada pengaruh penambahan beberapa ekstrak bahan pewarna alami terhadap aroma sosis ikan lele.

4. Penerimaan tertitnggi pada produk sosis ikan lele yaitu pada sosis ikan lele dengan penambahan ekstrak bit dengan kriteria warna krem keunguan, aroma tidak amis, rasa gurih, dan memiliki tekstur yang kenyal.

5. Kandungan zat gizi pada sosis ikan lele dengan penambahan ekstrak bit 12,6\% diantaranya energi $158 \mathrm{kkal}$ dalam 100 gram, protein $12,1 \%$, lemak $8,63 \%$, karbohidrat $8,02 \%$, air $69,4 \%$, dan abu $1,85 \%$.

6. Tingkat kesukaan terhadap warna sosis pada anak PAUD dan TK yaitu warna ungu (80\%).

\section{DAFTAR PUSTAKA}

Alamsyah, Y 2005. Sosis Tanpa Bahan Pengawet. Jakarta: PT Gramedia Pustaka.

Anonim 2002. Sosis. Bogor: IPB, No 9: Vol. 1. [online]//http://www.warintek.ristek.go.id/ pangan kesehatan/pangan/ipb/Sosis.pdf

Erwin, LT 2011. Gemar Makan Ikan 25 Cita rasa lele dan belut. Jakarta: PT Gramedia Pustaka Utama.

Muchtadi T, Sugiyono, Ayustaningwarno F. 2010. Ilmu Pengetahuan Bahan Pangan. Bogor: Alfabeta CV.
SEAFAST Center IPB. 2013. Merah Bit. http://seafst.ipb.ac.id (Diakses pada 7 Maret 2013 dan 16 Juni 2016).

Soebito, S 1988. Analisis Farmasi. Yogyakarta: UGM Pres.

Winneke, O. Ternyata Anak-anak Lebih Suka Makanan Warna-warni. http:// food.detik.com (Diakses pada 7 Januari 2012 dan 7 Agustus 2015).

Winarno, FG. 1997. Kimia Pangan dan Gizi. Jakarta: PT Gramedia. 